\title{
NEEDS ANALYSIS OF ENGLISH FOR SPECIFIC PURPOSES AT POLITEKNIK GIHON
}

\author{
Wiwik Damanik, Erika Sinambela, Arsen Nahum Pasaribu \\ Universitas HKBP Nommensen Medan \\ wiwiqdeeana@gmail.com,erikasinambela@uhn.ac.id,arsen.pasaribu@uhn.ac.id
}

Submitted: 2021-03-01

Accepted: 2021-05-01

\begin{abstract}
This thesis aims to explore the English language needs for English for specific purposes at Politeknik Gihon. The research was conducted in qualitative research using Hutchinson and Waters needs analysis, and multiple sources of data were used. The subjects of this research were 45 ongoing students in the academic year 2020/2021 and 6 former students. The study showed that $40 \%$ of students' proficiency was in the pre-intermediate level. Pre-intermediate ability means the students are in the stage of being able to use simple vocabularies and understanding a little English grammar. The questionnaire's result also revealed that the most needed skill is listening, followed by speaking, reading and writing were at the same stage. Moreover, students recommended learning activities through games and group work. Furthermore, listening to lectures and friends during class was the most needed in listening sub-skills, and in speaking sub-skills, asking and answering questions during class or group discussion was the highest percentage. Meanwhile, in reading sub-skills, students preferred reading exercise/test questions as the most needed. Then in writing sub-skills, the highest percentage revealed in writing reports or assignments. The interview result recommended adding the course hour of English class. The result of this study would give insight and become a guideline on how the English material should be designed at Politeknik Gihon.
\end{abstract}

Keywords: English for Specific Purposes; Needs analysis; English material

\section{INTRODUCTION}

The alignment of vocational education with business industries is still an important issue. In response to this demand, Politeknik Gihon, as one of a vocational higher education institution in Pematangsiantar, plays a critical role in preparing the next generation in terms of expertise, ability, and competence. It is also supported in one of Politeknik Gihon missions is producing graduates that are reliable, competitive, and must be sensitive and immediately respond to industrial needs.

Based on the evaluation phase in Politeknik Gihon, there is a need to revitalize the syllabus and learning process in line with the Strategic Planning of the Directorate General of Vocational Education (Vokasi, 2020) to achieve the link and match of education institution and work market. According to Sakarinto, General Secretary of Vocational Education (Kemdikbud, 2020), vocational education plays a strategic role in preparing young people in terms of skills, ability, and competence. Graduates are required to be skilled and able to work in the industry or as self-employed workers. The integration of vocational education with the business sector remains an essential problem, but the materials taught in educational institutions are still not fully matched with the industry's needs. Furthermore, he stated that, under the direction of 
Indonesia's Minister of Education and Culture, Makarim, the education sector must work closely with industry and the workplace (Kemdikbud, 2020).

Aside from mastering skills relevant to each study program's objectives, English is one of significant subject for Polytechnic students due to its status as a foreign language used in a variety of fields. The program emphasizes the importance of students mastering English for technical, academic, and professional purposes. Learning English can be seen from two perspectives. It can be learned for a variety of general and technical purposes. Polytechnic students, for example, use English for specific purposes. As a result, material designers and policymakers must take these factors into account.

English is one of the subjects that so essential to students. Students get greatly benefit from being able to communicate in English, especially ESP. If students have outstanding English skill, they can understand the content of reference books, the information from internet, scientific journals, and other sources of information. Seeing the essential of English, it is necessary to prepare English materials that meet students' needs. Lecturers or course designer must pay attention to the specificity and appropriateness of the content formulation. The materials for the English language module would not be successful in achieving their goals if they are not planned to meet the students' needs.

The research of needs analysis is used to gather information on learners' needs, according to Richard, as described in (Wahyono \& Puspitasari, 2016). Meanwhile, the analysis of needs, according to Nunan (Sukarni, 2020), is a method of gathering knowledge. Others scholars stated that Need analysis is critical for course design because it forms a conceptual foundation for all the other components of a formal language curriculum. Brown (1995), as quoted in (Margareta et al., 2017) stating that conducting needs analysis is an essential first step in designing a curriculum and as the systematic collection and evaluation of both subjective and objective data.

Moreover, further research stated that need analysis refers to the methods for collecting knowledge about students' needs. It concentrated on what students already understood as well as what they needed to know. According to Nunan as quoted in Indrasari (2016) defines needs research as "a concept used to gather information about learners and communication tasks" (p.75). Brown as quoted in Shing (Shing \& Sim, 2015) described needs analysis as "the assessment of both subjective and objective data in order to determine what is needed" that fulfill the students' and institute's requirements." The needs analysis is separated into two categories: target needs and learner needs.

The needs analysis approaches and models offered by Hutchinson \& Walters and Dudley-Evans and St. John (1998) are the well-known models that are currently used among 
many ESP researchers. Hutchinson and Walters (1987) expanded the definition and model of needs analysis from Chambers (1978) as quoted in (Basturkmen, 2010) and included the learning needs of the learners. In the context of ESP, they identified needs analysis as the types of linguistic features that learners must comprehend and/or produce in the situation in which they are engaged (Dudley-evans, 1998). As a result, two variables are used in their needs analysis model: target situation analysis and learning needs analysis.

Target situations analysis refer to "what the learner needs to do in the target situation" and the learning needs analysis refers to "what the learner needs to do in order to learn" (p. 54). As a result, it's more practical to consider the goal situation in terms of requirements, deficiencies, and desires. Target needs consist of necessities, lacks and want which describes as follows:

\section{Necessities}

Necessities refer to what learners need to know in order to be effective in the target situation. An entrepreneur, for example, will need to comprehend business letters, communicate efficiently in sales conferences, and obtain necessary information from sales catalogues, among other things.

2. Lacks

The gap between the student's current competences to his or her desired competence is considered lack. Furthermore, according to the English for Specific Purpose, lack refers to what the learner already knows, allowing the instructor or facilitator to determine which of the necessities the learner is missing (Hutchinson, Waters 1987) and (Breen, 1979).

3. Wants

The concept of wants, according to Hutchinson and Waters (1987), is perceived subjective needs of learners. Wants also implies that students must be aware of what they want to understand.

Meanwhile, the learning need is what students must do in order to learn; the entire ESP process is focused on learning rather than understanding or doing. It is necessary to consider the learning situation's destination or requirements: a mission is pleasurable, satisfying, manageable, and productive.

A similar checklist that used for target situation analysis can be used to assess learning needs. Why the learners taking the course, how they learn, what resources available, which learners, where the ESP course will take place, and when the ESP course will take place comprise a structure for evaluating the learning process. When performing a needs study, several factors should be considered, including the target language, the learners' competency 
and difficulty, learning styles, and learning strategies, and environmental factors (Basturkmen, 2010)

There have been lots of researches in needs analysis, in Indonesia context or abroad. Here are some previous researchers, such as (Ahmed Alsamadani, 2017), (Hidayat \& Aceh, 2018), (Indrasari, 2016), (Albassri, 2016) revealed that writing, reading and speaking were needed more. The majority of research findings shown that the implementation of needs analysis in vocational school has not been fulfilled and there is a need to upgrade teaching material in some aspects. Furthermore, some researchers focus on finding the students' needs which appropriate to their major study.

On the other hand (Arroyyani Lisa, 2019), (Margareta et al., 2017) analyze teaching materials and needs analysis based on ESP pattern of the 21st century, and gathering information on ICT-based English for nursing students. Another research focused on designing and implementing an aviation English instruction program (Lin et al., 2014), and on the development of English Academic purpose content (Sothan, 2015).

In this study, the researcher conducted a descriptive study to explain in detail some number of issues collected from the instruments in research such as observation by implementing proficiency test, questionnaire and interview. This study aims to identify language skills that are needed by the students and to develop English teaching materials in Politeknik Gihon.

\section{METHOD}

This study employed a descriptive qualitative research. The subjects of the research were 45 ongoing students at the academic year 2020/2021 and 6 former students who currently work in various fields. The objectives were to identify language skills are needed and to develop English teaching materials for the students of Politeknik Gihon. The researcher occupied a proficiency test, to see the basic knowledge of the students. The instruments used in this research were questionnaires for ongoing students, to identify students' needs in learning English for specific purposes. Meanwhile, the interview was implemented for the former students, to get their perceptions regarding English learning they experienced while they were students and their expectations on how should the English learning be ideally designed. In analyzing the data, the researcher applied Miles and Huberman (Miles \& Huberman, Dull \& Reinhardt, 2014)

\section{FINDING AND DISCUSSION}


The proficiency test that covered grammar and vocabulary consists of 50 items was applied on March $24^{\text {th }}$. Based on the proficiency test, can be seen that the majority of students' ability was pre-intermediate level means the respondents are in the stage of being able to use simple vocabularies and understanding a little English grammar. The interview of this study has been started since February 2021 as part of internal evaluation., meanwhile the questionnaire was implemented on March $25^{\text {th }}$. In this part, the research results are presented from figures 1 through 10 which reveal students' perception in answering needs analysis concerning lacks, wants, and necessities based on the questionnaire and the interview.

Figure 1. Students' perception regarding the importance of English for their study and future career

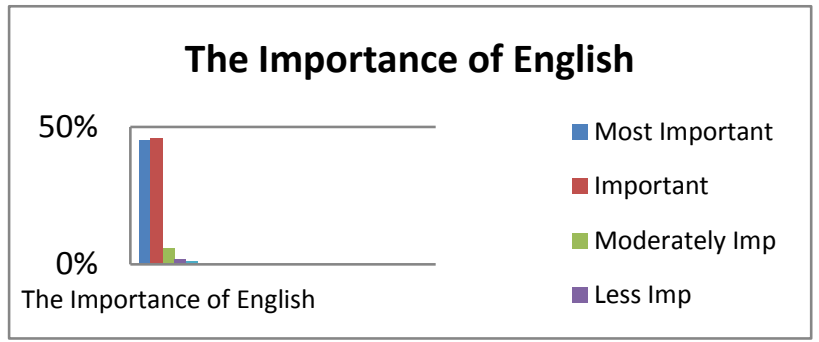

The graph above answers the question, how the students' perception regarding the importance of English for their study and future career. It can be seen that almost all respondents agreed that English is most important (45\%) and important (46\%) for their study and future career. Though there were a few students who stated that English is moderately important and less important.

Figure 2. The Importance of English skills to students' study and future work

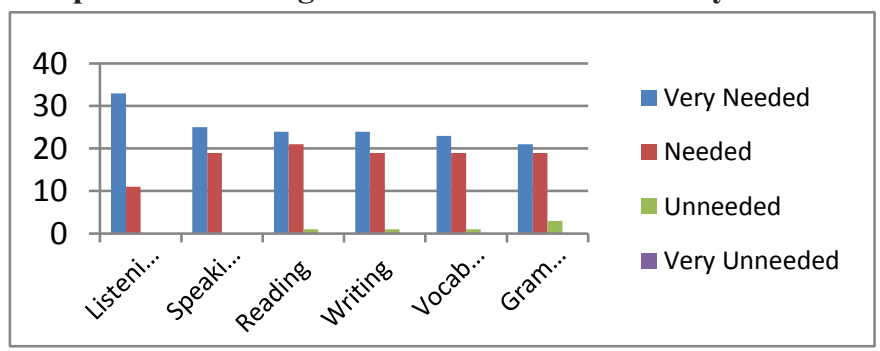

The diagram above reveals the range of the importance of English skills to the students' study and future work. Listening was the highest rank in the very needed option which was 73 $\%$ and $24 \%$ chose needed. It is followed by speaking skills, in which $55 \%$ of students said very needed and $42 \%$ said needed. Reading and writing are in the same range (53\%) and then vocabulary and the last was grammar. None of the students chose unneeded and very unneeded in all skills.

Figure 3. Students' preference regarding useful activities for learning English

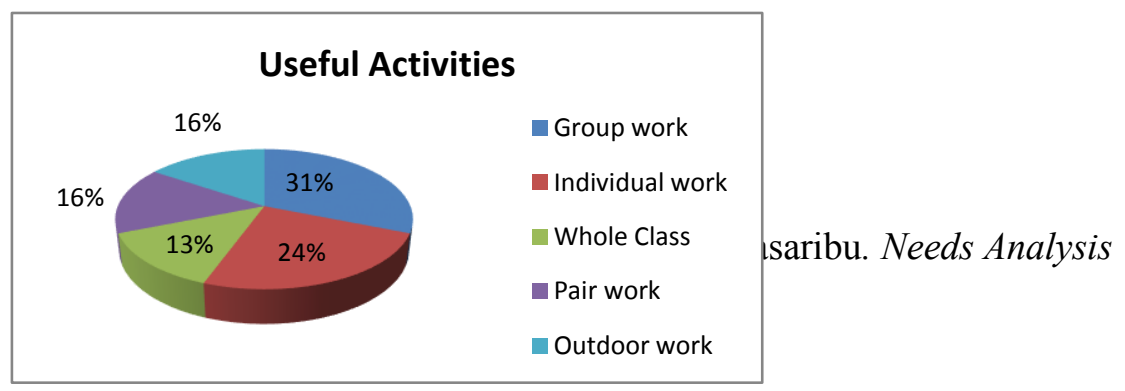


The above diagram represents the students' expectations for beneficial activities when performing tasks in English learning. Students favored group work 31 percent of the time, and individual work was preferred 24. They preferred group work to enable them to discuss when facing difficulties. Pair work and outdoor work came in second and third, respectively, with 16 percent. There are just 13 percent chose whole-class activities as their favorite activity.

Figure 4. Students' perception on the importance of English listening sub-skills

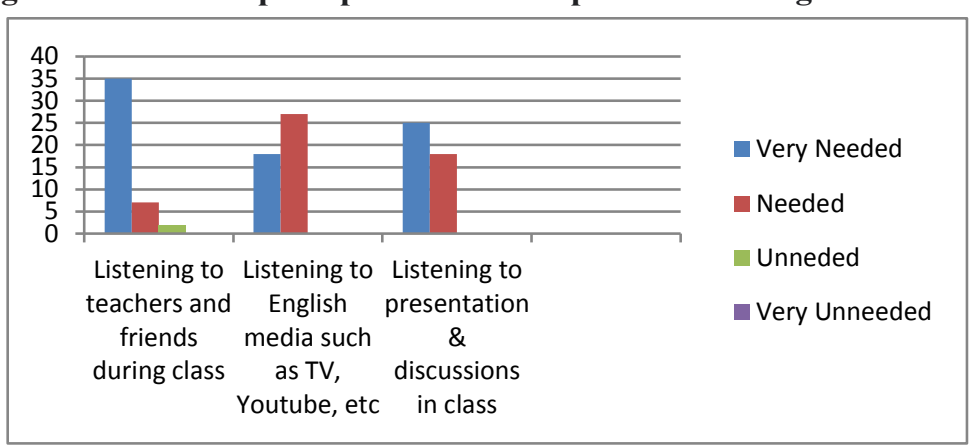

Figure 4 above illustrates that the majority of students agreed that listening to teachers and friends during class activities was very important (77.7\%), accompanied by listening to presentations and group discussions in class and seminars (55.5\%). There were just $40 \%$ of respondents who said that listening to English media such as television and YouTube was very important. It could be concluded as well that none of the students chose unneeded or very unneeded for any of the listening sub-skills.

Figure 5. Students' perception of the importance of English speaking sub-skill

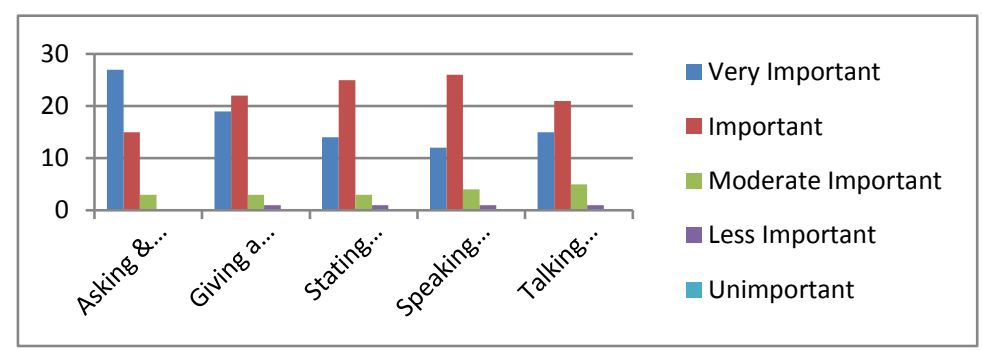

Figure 5 represents students' perspectives on speaking sub-skills. It shows that asking and answering questions during a class or group discussion is the most valuable skill (60 percent). The important option was chosen by $33 \%$ of students, while moderate was chosen by $6 \%$. Speaking to foreigners is significant to 58 percent of students, followed by expressing opinions or ideas about various topics during class activities. Other speaking sub-skills such as giving a presentation and talking over a virtual meeting such as Zoom, on the other hand, have the same percentage in the very important option, which is $33.3 \%$. 
Figure 6. Students' perception on the importance of English reading sub-skill

Figure 6 des "less important," v The graph shower rigorous reading $\mathrm{t}$

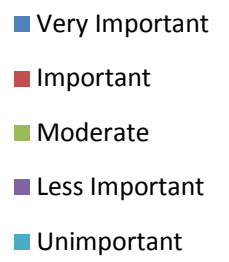

le of "very important" to kills were "unimportant." it they needed extensive t needed activity for the majority of them (62 percent). The second most needed activity is "reading a textbook," which receives $53 \%$ of the vote. The majority of them also believed they needed to be able to "search for material on the internet" to help them with their studies, which accounted for about $46 \%$ of the total.

\section{Figure 7. Students' perception on the importance of writing sub-skills}

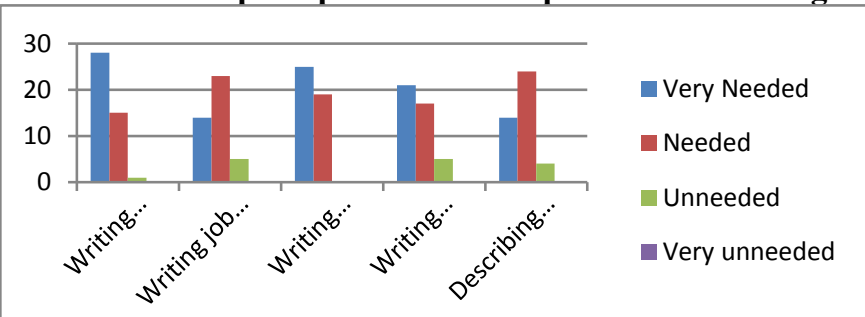

The diagram above illustrates that writing reports or assignments, writing job applications, writing examination answers, writing an email, and explaining diagrams, charts, and graphs are all part of the writing sub-skill. The highest percentage of very required revealed in "writing reports or assignment" with 62.2 percent percent and "writing examination answers" which is 55.5 percent. The next choice was to practice writing emails, which was chosen by 46.6 percent as a very important option. Meanwhile, illustrating diagrams, tables, and graphs needed the lowest amount of writing sub-skills.

Figure 8. The students' range of needed in vocabularies

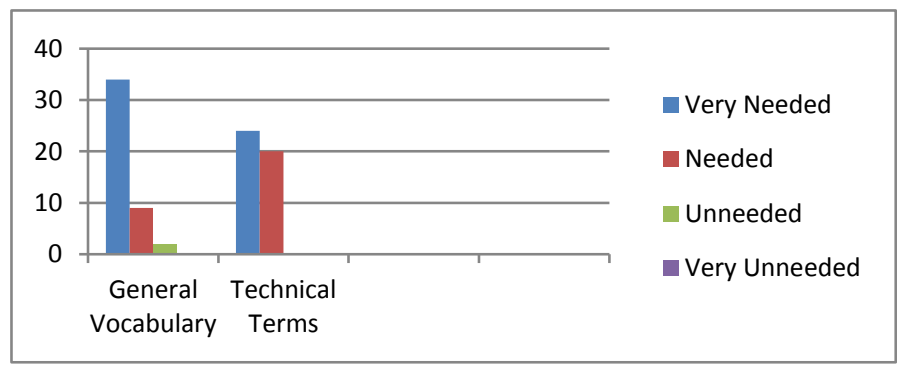

The diagram above describes that students perceived that they needed both vocabulary tasks. The patterns reported that "general vocabulary" as the very needed, which is $76 \%, 20 \%$ said needed and $4 \%$ said unneeded. On the other hand "technical terms", the students perceived it is very important is $53,3 \%$ and $44,4 \%$ students said needed.

\section{Figure 9. The needed range of grammatical structure}




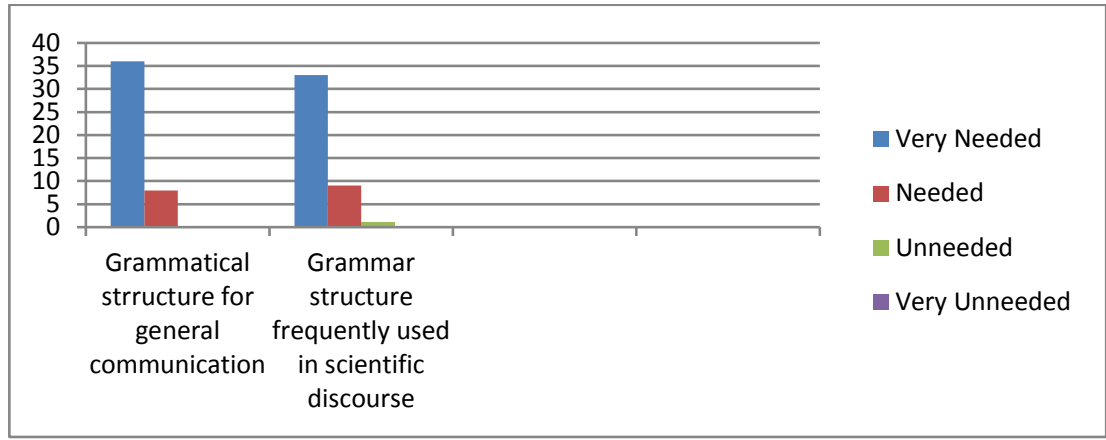

The figures above shows that the 45 students' perceptions of the grammatical structure were broad, from "the very needed" until unneeded." The diagram showed that most of the 45 students perceived that they extensively needed both grammar tasks. They rated "grammar structures for general communication" is the most needed with $80 \%$ and needed $17 \%$. However some students considered grammar structures for general communication unneeded, 3\% respectively. Meanwhile "grammar structure frequently used in scientific discourse", students said $73 \%$ with the very needed and $20 \%$ said needed.

Figure 10. Rank of English language functions that needed in the class

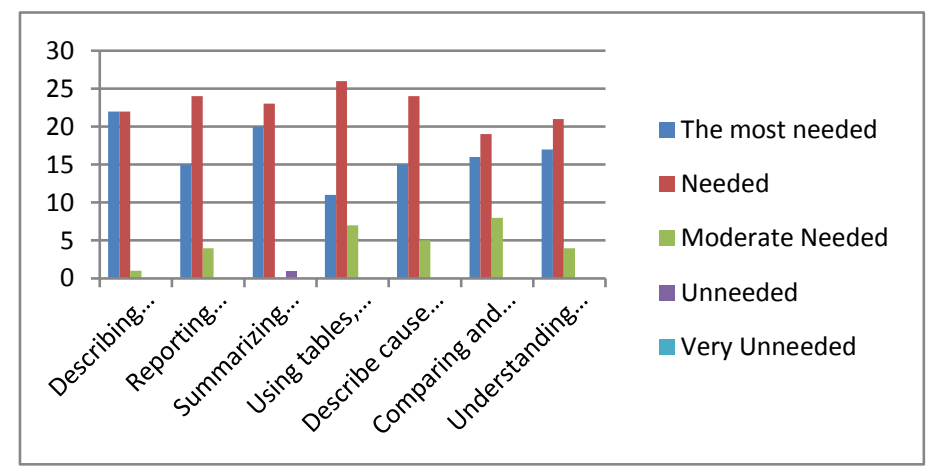

The importance of English language functions is represented in Figure 12. The 45 students' ratings ranged from "the most needed" to "do not need." The majority of students rated "describing processes and procedures" as the highest rank in the most needed option (49\%) and. The next language feature, which is required by 44 percent selected the most needed to "summarize the results of a group project or survey" and 51 percent of students selected needed. Meanwhile, the highest range of needed options is revealed in "using tables and graphs to summarized data" which is about $57 \%$.

The results have demonstrated the students' abilities are moderate. The instrument analysis also described listening as the most needed skill followed by speaking, reading, and writing. Additionally, the students stated the need for games and group work in-class activities. Regarding the importance of English sub-skills, the result showed different percentages though most were in very needed option. In the ESP course, need analysis assists lecturers or course designers in mapping ideas (Chatsungnoen \& Paweena, 2015). 


\section{CONCLUSION}

Based on the findings and discussion above, there are some learner variables of the English material design model, which focuses on four areas: a) the learners' background knowledge and proficiency in English language skills, b) the learners' interests and preferences, c) the learners' learning styles and strategies, and d) the learners' wants from the course. The students' interests and attitudes are also included in the redesigned model because the present study found that the students' interests and attitudes influenced the changes in their perceptions of their needs. Moreover, it is proposed for future need analysis, in obtaining information on students' background knowledge not only covered written text but also their listening and speaking capacity. However, it is important to note that needs analysis should not be a one-time event at the start of the course; rather, it should be a continuous process that is repeated over the length of the English for specific purpose program.

The education institution should also consider adding an English learning course hour, selecting teaching techniques and methods, and correlating English learning materials to program analysis. Additionally, the institution should recognize Indonesian policies and regulations while creating, designing, and implementing curriculum to ensure that it is always applicable to the Indonesian context as well as global perspective.

\section{REFERENCES}

Ahmed Alsamadani, H. (2017). Needs Analysis in ESP Context: Saudi Engineering Students as a Case Study. Advances in Language and Literary Studies, 8(6), 58. https://doi.org/10.7575/aiac.alls.v.8n.6p.58

Albassri, I. A. (2016). Needs-Analysis-Informed Teaching for English for Specific Purposes. Electronic Theses, Projects, and Dissertations., 274, 131. http://scholarworks.lib.csusb.edu/etd

Basturkmen, H. (2010). Developing courses in English for specific purposes. Developing Courses in English for Specific Purposes, 1-157. https://doi.org/10.1057/9780230290518

Brumfit, G. E. C. J. T. B. C.-P. P. (n.d.). General English Syllabus Design.

Chatsungnoen, \& Paweena. (2015). Needs analysis for an English for Specific Purposes (ESP) course for Thai undergraduates in a Food Science and Technology programme. https://mro.massey.ac.nz/bitstream/handle/10179/12359/02_whole.pdf?sequence=2\&isAll owed $=\mathrm{y}$

Dudley-evans, T. (1998). An Overview of ESP in the 1990s.

Hidayat, R., \& Aceh, B. (2018). A Needs Analysis in Learning English for Airline Staff Program. English Education Journal, 9(4), 589-613.

Indrasari, N. (2016). English for Specific Purposes: A Need Analysis at The Second Semester of Physics Education Students of IAIN Raden Intan Lampung in The Academic Year of 2015/2016. English Education: Jurnal Tadris Bahasa Inggris IAIN Raden Intan, 9(1), $161-172$.

Kemdikbud. (2020). Peta Jalan Pendidikan Indonesia 2020-2035. Kemdikbud, 1-74.

Lin, J., Wang, A., \& Zhang, C. (2014). Integrating Curriculum Design Theory into ESP Course Construction : Aviation English for Aircraft Engineering *. June, 219-227. 
Margareta, M., Safnil, S., \& Koto, I. (2017). a Need Analysis on Ict-Based English Material for Teaching and Learning of Reading for High School Students in South Bengkulu. JOALL (Journal of Applied Linguistics \& Literature), 2(2), 35-46. https://doi.org/10.33369/joall.v2i2.5953

Miles \& Huberman, Dull, E., \& Reinhardt, S. P. (2014). An analytic approach for discovery. In CEUR Workshop Proceedings (Vol. 1304, pp. 89-92).

Shing, S. R., \& Sim, T. S. (2015). EAP Needs Analysis in Higher Education : Significance and Future Direction. May.

Sothan, S. (2015). Exploring English Language Needs According to Undergraduate Students and Employers in Cambodia. International Journal of Linguistics and Communication, 3(1), 87-96. https://doi.org/10.15640/ijlc.v3nla11

Vokasi, D. P. (2020). Rencana Strategis Direktorat Jenderal Pendidikan Vokasi Tahun 20202024. Direktorat Jenderal Pendidikan Vokasi, 1.

Wahyono, E., \& Puspitasari, D. (2016). Students' Need Analysis of English Reading Skills. 1, $1007-1014$.

Waters, T. H. and A. (n.d.). ESP-A Learning Centred approach. 